\title{
Needs, parenting practices, and dissemination of information on social-emotional skills and development of infants
}

\author{
Necessidades, práticas parentais e disseminação de informação sobre desenvolvimento infantil e socioemocional do lactente \\ Necesidades, prácticas paternales y difusión de información sobre el desarrollo infantil y socioemocional del lactante
}

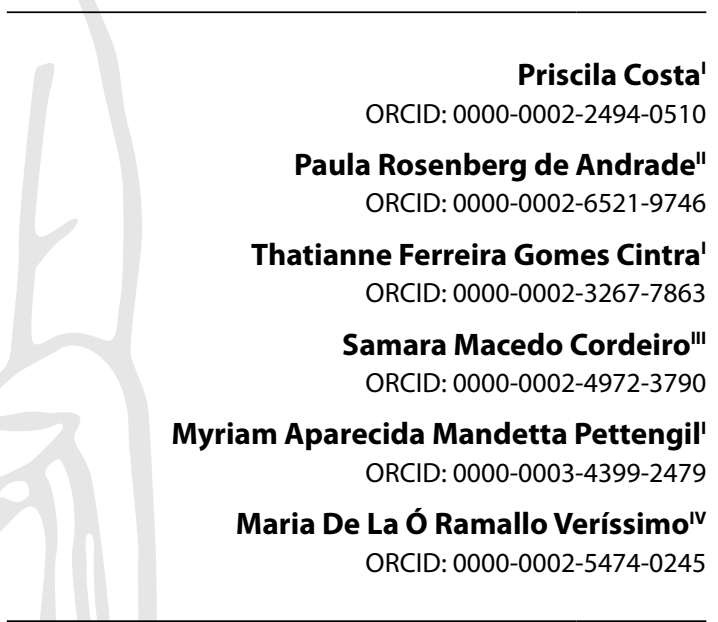

'Universidade Federal de São Paulo. São Paulo, São Paulo, Brazil. "Centro Assistencial Cruz de Malta. São Paulo, São Paulo, Brazil. I"'Santa Casa de São Paulo. São Paulo. São Paulo, Brazil. "Universidade de São Paulo. São Paulo, São Paulo, Brazil.

How to cite this article: Costa P, Andrade PR, Cintra TFG, Cordeiro SM, Pettengil MAM, Veríssimo MDLOR. Needs, parenting practices, and dissemination of information on socialemotional skills and development of infants.

Rev Bras Enferm. 2022;75(3):e20210296. https://doi.org/10.1590/0034-7167-2021-0296

\section{Corresponding author:}

Priscila Costa

E-mail:pricosta84@yahoo.com.br

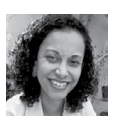

EDITOR IN CHIEF: Antonio José de Almeida Filho ASSOCIATE EDITOR: Fátima Helena Espírito Santo

Submission: 08-11-2021

Approval: 10-08-2021

\section{ABSTRACT}

Objectives: to describe the development of a technological innovation designed to identify needs, parental practices, and disseminate information on social-emotional skills and development of infants from the perspective of family members of infants on the social-emotional development of children. Methods: a report on the development of an innovation consisting of an educational group and a card game on social-emotional skills and development of infants. A spider-web concept map, content analysis and the Bioecological Theory of Human Development as a theoretical reference were used for data analysis. Results: the educational group and card game enabled the identification of information needs on child behavior and playing, and parenting practices focused on affectionate interactions, responsive caregiving, and socialization. Conversation with experienced parents, educational groups, apps, and health consultations were desirable dissemination strategies. Conclusions: the educational group and the card game represent an innovative, low-cost technology with potential for large-scale application in primary healthcare services.

Descriptors: Child Development; Infant; Needs Assessment; Information Dissemination; Primary Care Nursing.

\section{RESUMO}

Objetivos: relatar o desenvolvimento de uma inovação tecnológica para identificar necessidades, práticas parentais e disseminar informação sobre desenvolvimento infantil e socioemocional do lactente a partir da percepção de familiares de lactentes sobre o desenvolvimento socioemocional da criança. Métodos: relato sobre o desenvolvimento de uma inovação composta por grupo educativo e jogo de cartas sobre desenvolvimento infantil e socioemocional do lactente. $\mathrm{Na}$ análise dos dados, utilizou-se mapa conceitual do tipo teia de aranha, análise de conteúdo e a Teoria Bioecológica do Desenvolvimento Humano como referencial teórico. Resultados: o grupo educativo e o jogo de cartas permitiram identificar necessidades de informação sobre o comportamento infantil e brincadeiras, e práticas parentais voltadas às interações afetuosas, cuidado responsivo e socialização. A conversa com pais experientes, grupos educativos, aplicativos e consultas de saúde figuraram como estratégias de disseminação desejáveis. Conclusões: o grupo educativo e o jogo de cartas desenvolvidos representam uma tecnologia inovadora, de baixo custo e com potencial de aplicação em escala nos serviços de atenção básica.

Descritores: Desenvolvimento Infantil; Lactente; Determinação de Necessidades de Cuidados de Saúde; Disseminação de informação; Enfermagem de Atenção Primária.

\section{RESUMEN}

Objetivos: describir el desarrollo de una innovación tecnológica, para identificar necesidades, prácticas paternales y difundir información sobre el desarrollo infantil y socioemocional del lactante, a partir de la percepción de los familiares de los bebés, relacionado al desarrollo socioemocional del niño. Métodos: describir el desarrollo de una innovación compuesta por un grupo educativo y un juego de cartas referente al desarrollo infantil y socioemocional. En el análisis de datos utilizamos un mapa conceptual tipo tela de araña, análisis del contenido y la Teoría Bioecológica del Desarrollo Humano como marco teórico. Resultados: el grupo educativo y el juego de cartas, permitieron identificar las necesidades de información sobre el comportamiento y los juegos del niño, las prácticas paternales orientadas a las interacciones afectivas, cuidado receptivo y socialización. Las conversaciones con padres experimentados, grupos educativos, aplicaciones y consultas de salud, figuraron como estrategias de difusión deseables. Conclusiones: el grupo educativo y el juego de cartas desarrollado, representan una tecnología innovadora y de bajo costo con potencial de aplicación en escala en los servicios de atención primaria.

Descriptores: Desarrollo Infantil; Lactante; Evaluación de Necesidades; Difusión de la Información; Enfermería de Atención Primaria. 


\section{INTRODUCTION}

Early childhood development represents the foundation the acquisition of skills related to learning, socialization and emotional control. Multiple factors, such as health, nutrition, safety, protection, and sensitive and responsive care by family members and other caregivers influence child development ${ }^{(1)}$.

In this context, The Global Strategy for Women's, Children's and Adolescents'Health (2016-2030) prioritizes interventions to promote comprehensive early childhood development, including reinforcement of parenting skills towards responsive care to the children's socio-emotional needs ${ }^{(2-3)}$. Responsive care includes observing and responding to a child's movements, sounds, gestures, and verbalizations. The responsive relationship between caregiver and child can be expressed through eye contact, smiles, gestures, verbal communication, and hugs. These caring attitudes are the basis for protecting the child from injury and negative effects of adversity, recognizing and responding to illness, providing learning opportunities, and establishing bonds of trust, as well as social relationships ${ }^{(3)}$.

Therefore, the family is considered a fundamental element for care responsiveness towards the socio-emotional needs of the child. The Bioecological Theory of Human Development (BHDT), by Urie Bronfenbrenner, points out to the reciprocal interactions between the developing person and the environment as the "engine of development". Such interactions correspond to the process in the process-person-context-time (PPCT) bioecological model, which explains development as the product of person characteristics $(P)$, in interaction with contexts $(C)$, as a function of time $(T)$, both individual and historical ${ }^{(4)}$.

Given the importance of innovative strategies for the promotion of early childhood development, aiming to reduce inequalities in our society, the development and use of innovative technologies aimed at health promotion education on child development are essential, such as applications, games, websites, online primers, and others ${ }^{(5)}$. Therefore, the technological innovation reported in this study refers to the development of an educational intervention addressing the theme and social-emotional development of infant by means of an educational group and a card game with images that facilitate understanding of the theme, investigation of information needs, and parenting practices.

\section{OBJECTIVES}

To report on the development of a technological innovation to identify needs, parenting practices, and disseminate information on social-emotional skills and development of infants from the perspective of family members on their child's social-emotional development.

\section{METHODS}

\section{Ethical aspects}

The study was approved by the Research Ethics Committee of the Federal University of São Paulo and met the precepts of Resolution 466/2012. Family members were identified by the letter $\mathrm{P}$ (participant), and number (1 to 3 ).

\section{Study design, period, and location}

This is a report of technological innovation on the design and implementation of an educational intervention on infant socialemotional development. The design and the intervention were conducted out between February and June 2019. The intervention was delivered to family members of infants receiving health care in a philanthropic outpatient clinic that provides primary care in a region of high social vulnerability in the city of São Paulo. The innovation consisted of developing a card game (prototyping, testing, and reformulation) on social - emotional skills and development of infants, and an educational group with family members of infants in the healthcare service.

\section{Study protocol}

The card game on social-emotional skills and development of infants was developed by four professors of pediatric nursing from public universities in São Paulo, by a nurse with a PhD in pediatric nursing and active in the philanthropic health clinic, where the educational group was conducted, and by a undergraduate nursing student from a public university in São Paulo.

The game development stages included: prototyping, testing, and adjustment. The prototyping consisted on selecting the content, format and game mechanics. For the content, four milestones of the social-emotional development in the first year of a child's life were selected, using the Ministry of Health, "Child health booklet"(6) as technical reference, namely: smiling socially, playing hide-and-seek, imitating gestures such as clapping hands or saying goodbye, and showing what he or she wants with words, sounds, pointing or extending the hand. As for the format, the prototype was a board game with images illustrating the four milestones of social and emotional development and the age group when the child would be presenting that skill. The game mechanics involved the distribution of four cards to each caregiver. The cards contained phrases with actions that the child's caregivers could do to promote the four social-emotional developmental milestones on the board. The caregiver was required to read each card and match it to the corresponding developmental milestone.

The board game testing stage consisted of promoting a round of the board game with two caregivers of children in their first year of life at a philanthropic health clinic that provides primary care. In the testing, the caregivers appreciated the game's content and the illustrative images of the developmental milestones, but they had difficulties about the format and mechanics. Regarding the format, the caregivers indicated that the board game had a lot of visual information and questioned the age range in which each milestone was found, as they observed that their children developed those milestones before or after the age range described on the board. Regarding the game mechanics, limitations were identified in the format and dynamics. Because one of the caregivers was illiterate, the cards with phrases had to be read to him.

In the adjustment stage of the game, the content was maintained and the format and dynamics modified. The game consisted on four cards illustrating the developmental 
milestones, and four cards illustrating the caregivers' actions to promote those milestones. The final step included the engagement of an illustrator to produce the final version of the card game (Figure 1).

The educational intervention consisted of an educational group, facilitated by three nurses specialized in child development and experienced in conducting focus groups, followed by an interactive playful activity with a card game. The theoretical framework was based on Popular Education in Health ${ }^{(7)}$, which is a political-pedagogical praxis that guides the construction of educational processes and emancipatory social work, developed in a critical-reflective process in a joint development with the participants. This theoretical framework guided the development and implementation of the educational group, because it valued the popular knowledge of the infants' families and influenced the group dynamics, prioritizing dialogue and the shared construction of knowledge about the social-emotional development of infants.

For the educational group, the nurse in charge of the healthcare service, who was responsible for monitoring the infants' health, invited ten caregivers or guardians. They were invited during the child's routine nursing appointment, with reinforcement via whatsapp, with information such as date, time, and theme of the group. Of the ten caregivers invited, three attended the group, three explained their absence due to their work schedule, and the others did not respond.

\section{Data analysis}

For the data analysis of the educational group within the infants' families, the audio recorded from the group sessions was entirely transcribed. The content analysis was adopted as methodological reference, and the "Bioecological Theory of Human Development" (BTHD), as a theoretical reference. The letter "P" plus a number represent the participants' statements. The spider web concept map strategy was used, which allowed us to identify the main findings on information needs, parenting practices for promotion of social-emotional development, and preferences for the dissemination of this information to other families in the community, obtained from the statements of family members of infants.

\section{RESULTS}

Three families of children younger than one year of age participated in the intervention: two were first-time mothers, and one was a first-time grandmother. The participants' ages ranged from 21 to 53 years, and the children's ages ranged from five to seven months. The 90-minute educational intervention began with an ice-breaking dynamic in a conversation circle. This was followed by a focus group with three guiding questions. At the end, a collaborative card game was used by the family members.

Conducting an innovative educational intervention on socialemotional development with family members of infants proved to be a rich learning opportunity about the information needs of families, parenting practices usually adopted and strategies for dissemination of knowledge on this complex topic.
Chart 1- Stages, strategies, and rationale of the educational intervention for families on social-emotional development of infants, São Paulo, São Paulo, Brazil, 2019

\begin{tabular}{|c|c|c|}
\hline Stages & Strategies & Rationale \\
\hline $\begin{array}{l}\text { Ice-breaking } \\
\text { dynamics: } \\
\text { introduction } \\
\text { to the theme } \\
\text { "infant's social- } \\
\text { emotional } \\
\text { development". }\end{array}$ & $\begin{array}{l}\text { A conversation circle using } \\
\text { metaphors developed from } \\
\text { a study with the Brazilian } \\
\text { population aimed at facilitating } \\
\text { communication about infant } \\
\text { development }{ }^{(8)} \text {. The metaphor } \\
\text { of the ball (alluding to giving } \\
\text { and receiving) and the canoe } \\
\text { (representing the need to be in } \\
\text { tune with the other) was adopted } \\
\text { to talk about the relationship } \\
\text { between caregiver and child. }\end{array}$ & $\begin{array}{l}\text { The complexity } \\
\text { of the theme, } \\
\text { and the need } \\
\text { to attribute } \\
\text { concreteness } \\
\text { to abstract } \\
\text { concepts. }\end{array}$ \\
\hline $\begin{array}{l}\text { Focus group } \\
\text { guiding } \\
\text { questions }\end{array}$ & $\begin{array}{l}\text { What information do you think } \\
\text { would help you and other parents } \\
\text { to know more about how infants } \\
\text { interact with adults to communicate } \\
\text { their feelings, desires, and likes and } \\
\text { dislikes? } \\
\text { Thinking about the ballgame of the } \\
\text { relationship between you and the } \\
\text { child, what do you think is important } \\
\text { to know to facilitate the emotional } \\
\text { development of the infant and good } \\
\text { relationships with others? } \\
\text { How do you think this information } \\
\text { could be taken to other parents like } \\
\text { you? }\end{array}$ & $\begin{array}{l}\text { The questions } \\
\text { began by } \\
\text { recovering the } \\
\text { knowledge } \\
\text { of the } \\
\text { participants, } \\
\text { by valuing it, } \\
\text { and by making } \\
\text { them feel } \\
\text { accepted in } \\
\text { a dialogical } \\
\text { process, } \\
\text { instead of a } \\
\text { "top-down" } \\
\text { process. }\end{array}$ \\
\hline $\begin{array}{l}\text { Playful } \\
\text { interaction } \\
\text { between } \\
\text { parents and } \\
\text { ending }\end{array}$ & $\begin{array}{l}\text { Use of a card game with } \\
\text { illustrations of the social-emotional } \\
\text { developmental milestones of } \\
\text { the infant: social smiling; playing } \\
\text { hide-and-seek; clapping hands; } \\
\text { pointing at objects, people, or } \\
\text { animals; as well as the caregiver's } \\
\text { actions. Caregivers were required } \\
\text { to visualize the developmental } \\
\text { milestone illustrated and choose } \\
\text { a card that corresponded to the } \\
\text { parenting practice promoting each } \\
\text { milestone. }\end{array}$ & $\begin{array}{l}\text { Stimulating } \\
\text { interaction } \\
\text { between } \\
\text { participants by } \\
\text { involving them } \\
\text { in a common } \\
\text { task promotes } \\
\text { group feeling } \\
\text { and perceived } \\
\text { control. }\end{array}$ \\
\hline
\end{tabular}
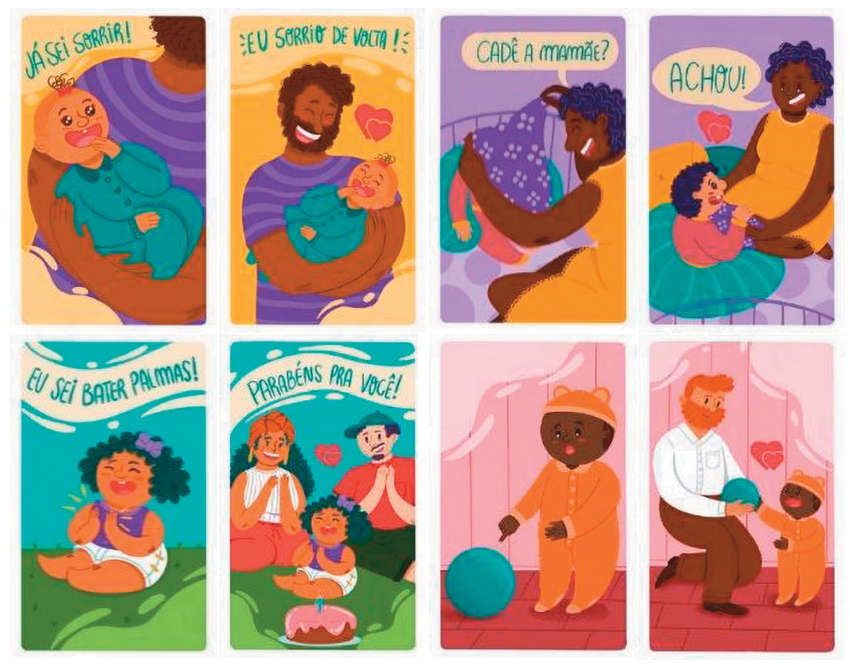

Figure 1 - Card game about the social-emotional development of the infant, São Paulo, São Paulo, Brazil, 2019 
Regarding the information needs, the family members stated difficulties in understanding the infant behavior and meeting social-emotional needs in the first months of the child's life. The participants stated the challenges in meeting the need to provide opportunities for playing, because the infant does the same activity for a short period of time. The perception of the baby's characteristics demonstrates the mother's in tune with his/her particularities, an aspect that highlights the construct "Person".

He does a little bit of each thing. He picks up the toys, plays a little bit, and then he gets tired. Then, he wants to watch TV a little bit, and he gets tired and wants to do something else, and so on. He gradually gets tired. (P1)

Regarding parenting practices, the importance of interaction between caregiver and child and socialization with other adults was found [BTHD construct: Process], as well as meeting the infant's emotional needs expressed by crying, asking for lap and attention [BTHD construct: Person] were stated by participants as important ingredients in promoting the infant's good development.

I was always affectionate, even when he was inside my tummy, I touched it, talked to him. I played songs for him, to be heard inside my belly. I believe he corresponded because he used to kick a lot. (P1)

Does he want more attention? Or is it just a child thing, you know? Some people say that it is a tantrum, but I believe it's not, you see? There's no point in leaving him crying, agonizing, because it will make the situation worse. (P1)

My grandson is a five-month-old child. Some children at eight months old, one year old are not like him. Why is that? That is because of the way of caring, the mother's affection, and the father's affection. It is important to have contact with every people. It doesn't matter if it's not from the family or if it's from outside, but the contact with people. (P2)

Regarding strategies for disseminating knowledge on socialemotional development of the infant, family members stated the importance of connecting with others, who have previous experiences as a parent, use of apps, virtual and in-person parenting groups, and appointments at healthcare services [BTHD Construct: Context and Process].

Talking to those who are more experienced is helpful. Since I was pregnant l ask questions, I learned some things from friends, my mother, or in the apps I have on my cell phone. (P3)

I think that a virtual group, where individuals can exchange ideas, information; a three-minute vides to spread this knowledge. Eventually, if possible, even just once a month, everyone would meet and share more ideas in person. (P1)

What I learned was learned at the meeting, at the appointment, at the clinic. (P2)

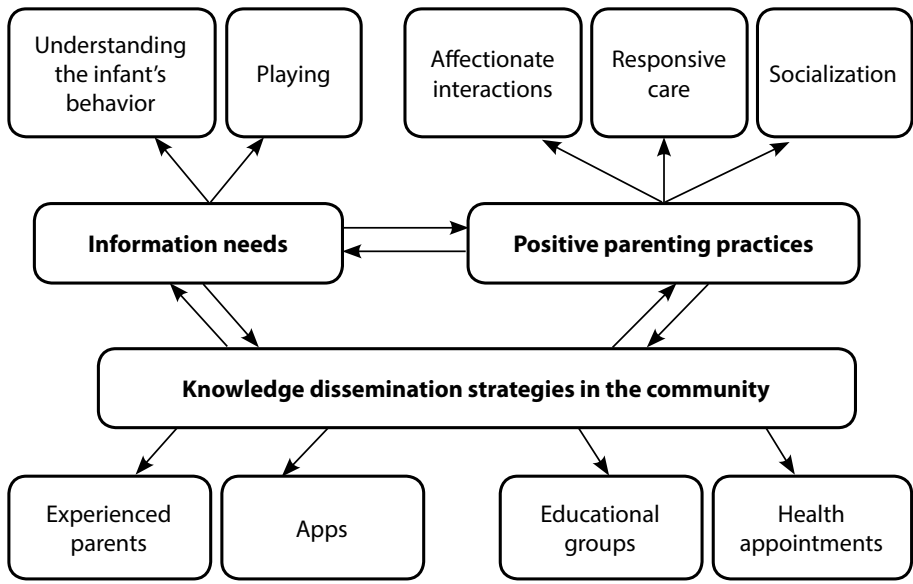

Figure 2 - Spider-web conceptual map on families' information needs, practices promoting social-emotional development of the infant, and strategies for knowledge dissemination in the community, São Paulo, São Paulo, Brazil, 2019

Relative to the card game, participants helped themselves in the task of connecting the illustrated developmental milestone, and the corresponding parenting practice. The pairing of the four cards showed the importance of offering affection, smiling and talking to the child.

\section{DISCUSSION}

The development of technological innovation identified the power of an educational intervention that addressed a complex theme such as social and emotional development for family members of infants. The adoption of playful resources such as the card game, dialogical approach, and encouraging interaction, proved to be positive, as it placed the professional in the situation of one who understands that different knowledge should not be used to exercise domination.

The educational group strategy and card game gave a voice to the families in a playful manner to recognize their needs for information, parenting practices, and suggestions for disseminating this knowledge to other families in the community. Interventions of this nature have great potential for promoting child development. Health education in primary care is one of the main elements for promotion of healthy development, as it provides the child's caregiver with the tools to provide sensitive, critical, and reflective care. Child care in the primary care, health promotion actions and surveillance of child development performed by nursing are able to minimize situations of vulnerability and risks to child development ${ }^{(9)}$.

The educational intervention provided nurses with the opportunity to disseminate knowledge on infant development in the first year of life, as well as practices to support it. The card game was useful to create a relaxed atmosphere, to practice reflection and decision making with mutual help, and to understand the strengths and difficulties related to developmental milestones and the parenting practices that stimulate them.

The knowledge addressed in the educational intervention showed the close synergy between the infant and the mother, as well as the strong influence of maternal behavior on the 
social-emotional development of the infant ${ }^{(10)}$. A study ${ }^{(10)}$ investigating 61 first-time mothers in the sixth and eighth postpartum months revealed that infants of mothers with higher levels of sensitive care and bonding with the baby had greater socialemotional skills and better behavior ${ }^{(10)}$.

The participants expressed concerns about how to respond to the infant's needs for lap, attention, and play. However, they reported practices that were sensitive and responsive to the infant's emotional needs by means of touch, affection, conversation, socialization, and the proposition of multiple plays. Multiplicity of play is a common practice reported in a survey of 1,000 family members (father, mother, grandparents, uncles) of children from zero to three years old living in Brazil, showing the preponderance of playing with the child's toys, followed by playing with more active games (jumping rope, hide-and-seek, catch, etc.), in playgrounds, squares and parks close to home for classes A/B1 and dancing with infants for families living in the countryside and class $D$ in the capitals ${ }^{(11)}$.

With regard to the strategies for dissemination of knowledge about child development, this same study ${ }^{(11)}$ showed that the sources of information most used by those responsible for infants under three years of age were family members, education received, friends, internet materials and youtube, and lastly medical personal and church. Unlike the desired, the sources of information linked to public policies had little reference among all groups of respondents (maximum of $12 \%$ for class D. The use of the child health booklet, as a guidance tool for adults responsible for the child ranged between $20 \%$ (class D), and 31\% (classes $\mathrm{B} 2 / \mathrm{C})$, living in metropolitan regions and with basic education ${ }^{(11)}$. At the same time, as well as the data from the activity reported here, it is evident that different approaches and contexts can act synergistically in the promotion of development-promoting care.

\section{Study limitations}

Although the innovative and potentiating character of knowledge and experience sharing, a limitation of this report is the reduced number of participants in the educational intervention because of difficulties in involving families in a group activity in a healthcare service during the week.

\section{Contributions to the public policies}

A contribution of this report to the practice of primary care professionals includes the development of feasible, low-cost, and potentially applicable innovations at a significant scale to disseminate knowledge on child development to families with young children. The educational group and the card game proved to be sustainable strategies that can be incorporated into current public health policies in primary care, by professionals working in the Family Health Strategy (FHS), Child Educational Center (CEC) or in the Reference Center for Social Assistance (RCSA). This innovation can be incorporated, by health, education or social care professionals, who work with families of young children, when performing actions to promote the child development and support parenting.

\section{FINAL CONSIDERATIONS}

The game and educational group facilitated the development of an innovative, low-cost technology with potential for application at large scale to address a fundamental theme such as the social-emotional development of infants. Reporting the development of this innovation also helped to recognize the information needs, parental care, and preferences regarding knowledge dissemination strategies on social-emotional skills and development of infants for family members of children who use a public and philanthropic healthcare service. The combination of virtual strategies to presential health care strategies seems to be a promising trend for the implementation of evidence-based care in the promotion of early childhood development in primary healthcare services in Brazil.

\section{FUNDING}

This research was funded by the National Council for Scientific and Technological Development (CNPq) at process 409867/2018-7.

\section{REFERENCES}

1. Richter LM, Daelmans B, Lombardi J, Heymann J, Boo FL, Behrman JR, et al. Investing in the foundation of sustainable development: pathways to scale up for early childhood development. Lancet. 2017;389(10064):103-18. https://doi.org/10.1016/S0140-6736(16)31698-1

2. Britto PR, Lye SJ, Proulx K, Yousafzai AK, Matthews SG, Vaivada T, et al. Nurturing care: promoting early childhood development. Lancet. 2017;389(10064):91-102. https://doi.org/10.1016/S0140-6736(16)31390-3

3. World Health Organization. Nurturing care for early childhood development: a framework for helping children survive and thrive to transform health and human potential [Internet]. Geneva: WHO; 2018[cited 2021 Mar 13]. Available from: https://apps.who.int/iris/ bitstream/handle/10665/272603/9789241514064-eng.pdf

4. Rosa EM, Tudge J. Urie Bronfenbrenner's theory of human development: its evolution from ecology to bioecology. J Fam Theory Rev. 2013;5(4):243-58. https://doi.org/10.1111/jftr.12022

5. Silva HL, Bezerra FHG, Brasileiro IC. Evaluation of educational materials targeted at the psychomotor development of the Child. Rev Bras Promoc Saude. 2017;30(3):1-6. https://doi.org/10.5020/18061230.2017.6358

6. Ministério da Saúde (BR). Caderneta de saúde da criança-passaporte da cidadania. Brasília, DF: MS; 2013.

7. Ministério da Saúde (BR). Política nacional de educação popular em saúde. Brasília, DF: MS; 2012. 
8. Baran M, Sauma S, Siqueira P. Valores e metáforas: para a comunicação do conhecimento científico sobre o desenvolvimento na primeira infância no Brasil: circular FrameWorks para o núcleo ciência pela infância. [Internet]. Washington, DC: FrameWorks; 2014 [cited 2021 Mar 1]. Available from: https://www.fmcsv.org.br/pt-BR/biblioteca/estudo-frameworks---valores-e-metaforas/\#

9. Pereira MM, Penha TP, Vieira DS, Vaz EMC, Santos NCCB, Reichert APS. Nursing educational practice in primary health care aimed to healthy child development. Cogitare Enferm. 2015;20(4):767-74. http://doi.org/10.5380/ce.v20i4.41649

10. Behrendt HF, Scharke W, Herpertz-Dahlmann B, Konrad K, Firk C. Like mother, like child?: maternal determinants of children's early socialemotional development. Infant Ment Health J. 2019;40(2):234-47. https://doi.org/10.1002/imhj.21765

11. Fundação Maria Cecilia Souto Vidigal. Interações: comportamentos de pais e cuidadores de crianças de 0 a 3 anos [Internet]. São Paulo: FMCSV; 2020[cited 2021 Mar 27]. Available from: https://omlpi-strapi.appcivico.com/uploads/primeirissima_infancia_interacoes_ comportamentos_pais_cuidadores_criancas_0_3_anos.pdf 